\section{THE HEALTHCARE CONSUMER: SATISFIED OR HAPPY - A REVIEW}

KEY WORDS:Customer satisfaction, Patient satisfaction, Customer Happiness, Patient Happiness.

\section{Bharati Grace Ebenezer Peters*}

\section{Dr. Usha Tiwari}

Doctoral Fellow, Women Institute for Studies in Development Oriented Management (WISDOM), BanasthaliVidyapith, Rajasthan, India. *Corresponding Author

Associate Professor. Physical Education, Central University of South Bihar, Gaya, Bihar, India

INTRODUCTION: Customer satisfaction is an important aspect for any organisation. Satisfied customers, ensure loyalty to the organisation. Building customer loyalty has an advantage (Bansal and Gupta, 2001). Much academic research has taken place in this field (Stenbery, 1997).The concept of Happiness has been around for centuries. Early philosophers and great thinkers, date back to Aristotle, Plato and Socrates, in the western world and, closer to home we have Buddha,

터 with his Middle Path; Confucius and the Dalai Lama. Satisfaction denotes less stress, which can lead to health, whereas happiness indicates not just health but exceeding customers' expectation too.

OBJECTIVE: The review was done mainly through published articles to gain an insight in the areas of happiness and satisfaction and their measurements.

METHODOLOGY: The review used descriptive cross-sectional research design using secondary sources related to satisfaction and happiness. Very few studies have focused on the patient in terms of both satisfaction as well as happiness. The review mainly identified concepts of satisfaction and happiness, for services in industry and was then related to the healthcare industry.

RESULTS: A lot of efforts went into the concept of Satisfaction; however, Happiness was the new trend.

CONCLUSION: The healthcare industry is unique, and management and delivery of customer experience service excellence is the ultimate goal.

\section{INTRODUCTION}

There is ample literature on management discipline describing customer satisfaction and customer emotions thereby establishing with evidence that customer emotions are an imperative element of satisfaction construct (Oliver \& Westbrook, 1993; Cronin, Brady and Hult, 2000; Barsky and Nash, 2002). The focus on emotions of customers has evolved from the approach of earlier studies that gave primary importance to the cognitive aspect of satisfaction (Liljander \& Strandvik, 1997; Bagozzi, Gopinath and Nyer, 1999; Oliver, 2010). The difference between Happiness \& satisfaction is that Happiness leads to health, includes satisfaction, is an emotion $\&$ has a wide range. Satisfaction has no mention of health, is a component of happiness, is cognitive in nature and limited in range. The complex interactions of various emotions, cognitive appraisals, affective responses and satisfaction need to be analyzed from the mental affinity of a customer which is demonstrated in normal situations as an expression of happiness (Compeau, Grewal and Munroe, 1998; White, 2010).

Thus it can be stated that a consumer doesn't merely want to be "satisfied" but sincerely desires to be happy after using a product or a service (Rust \& Zahorik 1993). Despite spending millions of dollars on improving customer satisfaction and developing brand innovations and brand equity, the consumer seems to be lesser happier than they were nearly five decades ago (Richard, 2001).

\section{OBJECTIVE}

The review was done mainly to gain an insight in the areas of happiness and satisfaction.

\section{METHODOLOGY}

The review used descriptive cross-sectional study design from various secondary sources on customer satisfaction and happiness, and on patient satisfaction and happiness. Electronic searches were conducted in the following search database indexed open access and peer-reviewed journals that addressed research in marketing, epidemiology, psychology, mathematical population, rehabilitation, health economics, Sage Publications, Springer Publication social sciences. Search was also done in The UAE Ministry of Health and Prevention and Dubai Health Authority websites, reports and blogs, websites like Google Scholar and Wiley Online Library.

Data:The search used key words like customer care, customer satisfaction, happiness, and well-being, patient feedback, patient satisfaction, and patient happiness.

The articles searched were in English language. The focus of the review was mainly on the various studies done on satisfaction, well-being and happiness. The study excluded staff and safety issues. All articles were sorted out based on inclusion and exclusion criteria. Those articles that fell in the exclusion criteria were considered not eligible and were discarded.

\section{RESULTS AND DISCUSSION}

There is a growing evidence of shift from Customer satisfaction towards Customer happiness. In the healthcare sector, too this is becoming more evident.

Customer satisfaction is the difference between the customer expectation and what he receives in connection with the fulfilment of a need, desire or goal (Hansemark \& Albinsson, 2004).

In the healthcare industry, the measurement of patients' satisfaction has become prominent in American Healthcare System (Deloitte, 2018). Mystery shopping has been used to measure customer satisfaction recently in the service industry. This has also been extended to the health sector.

The concept of Happiness has been around since time immemorial from eminent philosophers like Aristotle, Plato, Socrates, Confucius \& Dalai Lama. There are many scales to measure happiness designed by eminent psychologists tooPANAS, Subjective well-being, Satisfaction with Life, Oxford Happiness Scale, etc. All of these address the topic of Happiness from the point of view of Life and general wellbeing.

This study presents findings from four main aspects Customer satisfaction, Patient satisfaction, Customer Happiness, Patient Happiness. 


\section{Customer Satisfaction}

As mentioned earlier, customer satisfaction is imperative for any organisation. In the past, research work focused on customer satisfaction only and hence, the companies gave importance to customers' needs and wants. A study by Hoyer and Macinnis (2001), found that customer satisfaction is linked with the emotions of acceptance, relief, excitement, happiness and delight while undergoing a purchase process or experiencing a service offered. So, the customer shows various dimensions of emotions that may or may not be expressed. According to the study, many factors influence the level of customer satisfaction. Hokanson (1995) in his study on customer satisfaction index put forth factors such as friendly and courteous staff, knowledgeable support by the employees, billing timeliness, service quality, and value for money etc.

Customer satisfaction occurs when expectations are met. When experience exceeds expectation, the level of satisfaction increases. Similarly, when experience is less than expectation, the customer gets dissatisfied. So it can be seen that experience and expectations are directly related. The concept of service quality during the $80 \mathrm{~s}$ was based on the research work done in the field of cognitive psychology (Hoffman, 1986). This was based on real time performance that could be benchmarked as a standard (Anderson, 1973).

A customer's perception of service quality occurs when the customers compare their expectations to the actual service received (Gronroos, 1984). Customer satisfaction results in customer loyalty, repurchase interest and word of mouth marketing (Brady \& Cronin, 2001b). It is therefore of utmost importance to understand the customers' expectation, their perception and experience to develop a competitive advantage in the market place. A firm must be able to translate the intangible service into tangible elements by market researcher. The current trend is moving from a productoriented approach to a service-oriented one.

Customers usually compare their past experience with the present expectations to make judgments on satisfaction level. However, this does not guarantee customer loyalty. It is possible that fully satisfied customers can switch brands (Jones \& Sasser, 1995), due to a change in future expectations. In short we can surmise that it may not be possible to measure customer satisfaction directly. Also, it is necessary to measure not just the current experience but future expected experience, as well (Anderson \& Fornell, 2000).

\section{Patient Satisfaction}

Literature review reveals initiatives on customer satisfaction, its measurement and its application in the healthcare industry in the form of the Press Ganey Survey and Mystery shopping. The measurement of patient satisfaction has gained prominence in the American Healthcare System (Deloitte, 2018). The Press Ganey Survey, approved by National Quality Forum (NQF), has been used by the US Govt., in reimbursement models. According to the American College of Emergency Physicians (ACEP), information on healthcare providers' performance and hospital services can be derived through the patient survey by using Press Ganey Survey.

Mystery Shopping uses researchers as dummy staffs to get satisfaction feedback from customers about processes. It has effectively found out hidden weaknesses. These have been evidenced through various studies ( Steinman, Kelleher, Dembe, Wikizier and Hemming, 2012). It is mainly used to monitor staff performance and quality of service provided. It helps you to test your services and check out if there is a rival or competitor, is an ideal way of getting customer feedback in an amicable manner, and helps take steps to improve weaknesses that have been identified. In the healthcare industry, the feedback received enables leaders to take initiatives to improve services to retain their patients. (Betancourt, Green, Carrillo and Park, 2005).

\section{Customer Happiness}

The term happiness has been defined by philosophers and psychologists. There are two existing views. The first is hedonic, involving pleasant feelings and the second is eudemonic implying feelings of virtuosity and morality (Ryff and Singer 2008). The hedonic view has two main elements life satisfaction, relationship maintenance, etc. and affect balance based on positive feelings and less negative feelings (Schimmack, 2008). Research in psychology on emoticons and moods reveals that the most important part is the hedonic plain that examines the situation of relative range of pleasantness and unpleasantness in life (Watson et al., 1995).

The term happiness has not been researched in marketing in detail and most studies focus on customer satisfaction and loyalty. Happiness has been interchangeably used with satisfaction (Layard, 2005). The concept came into being only recently when strategies focused on internal and external customers (Laihonen, Jääskeläinen and Pekkola, 2014). It was earlier believed that a satisfied customer was happy. However, the changing mindset and preferences of the customer, compelled companies to offer something over mere satisfaction to develop loyalty and make customers happy (Heskett, Jones, Loveman, Sasser \& Schelsinger, 2011). An organization, therefore, needs to build customers' trust for a significant and positive influence on customer loyalty and happiness (Kantsperger \& Kunz, 2010). So the brand experience should enhance happiness over a prolonged period. Happiness that gives an extra unexpected benefit by paying a very low cost delights the customer to a heightened level (Rust \& Zahorik 1993).

\section{Patient Happiness}

Happiness measurements stem from the OECD guidelines on measuring subjective well-being (SWB) issued in the year 2013 (OECD, 2013). The guidelines given by OECD lead to an application of anchored scale for measurement (Global Happiness Council,2018).

In the healthcare industry, the quality of care is one of the most debated issues (Francis, 2013). Patient experience offers insights into the quality of care in comparison with the emotional experience of the patient (Murphy, Bruce, Mercer and Eva, 2009). Consumer Assessment of Healthcare Providers and Systems (CAHPS) is an AHRQ program that began in 1995. The main aim of this programme was understanding patient experience with healthcare. The Agency for Healthcare Research and Quality, deals with two important aspects of healthcare viz. Research and Quality. CAHPS provides insight into the patient experience at various points in the healthcare system.

\section{CONCLUSION}

The vast literature base developed by experts, research scholars, provides a detailed insight into customer satisfaction, loyalty and happiness. Despite rich literary development and various academic research, no studies have been conducted to find out the relationship between healthcare organizations and patients happiness; however, initiatives have been taken.

\section{RECOMIMENDATIONS}

I.The concept of positivity reduces burden of litigations.

ii. Organizations would benefit greatly by nurturing internal customers so that external ones are retained.

iii. Regular attention must be given to feedback particularly when it is negative.

iv. Customer loyalty and advocacy must be prioritized.

v. Suggestions for improvement by customers must be implemented through various projects.

\section{REFERENCES:}

1. AHRQ (2017). National Healthcare Quality and Disparity Report, 2017, Rockville, MD: Agency for Healthcare Research and Quality; September 2018. AHRQ Pub. No. 18-0033-EF.

2. Anderson, E., \& Fornell, C. (2000). Foundations of The American Customer Satisfaction Index. Total Quality Management, 1 (1), 869-882. http:// dx. doi. 
org/ 10.1080/09544120050135425

3. Anderson, R.E., (1973). Consumer Dissatisfaction: The effects of disconfirmed expectancy on perceived product performance. Journal of Marketing Research 10,38-44

4. Bagozzi, R.P., Gopinath, M., \& Nyer, P.U. (1999). The role of emotions in marketing, Journal of the Academy of Marketing Science, 27(2), 184-206

5. Bansal, S. \& Gupta, G., (2001). Building Customer Loyalty Business-toBusiness Commerce.Tata McGraw-Hill, 2001,pp.3-25.

6. Barsky, J. \& Nash, L (2002). Evoking Emotion: Affective Keys to Hotel Loyalty, Cornell Hotel and Restaurant Administration Quarterly, 43(1),39-46.

7. Betancourt, J.R, Green, A.R, Carrillo, J.E., Park, E.R (2005). Cultural competence and health care disparities: key perspectives and trends. Health Aff. 2005;24:499-505.

8. Brady, M.K., \& Cronin, J.J. Jr. (2001). Some New Thoughts on Conceptualizing Perceived Service Ouality: A Hierarchical Approach. Journal of Marketing, 65(3), 34- 49. doi: 10.1509/jmkg.65.3.34.18334

9. Campeau, L.D., Grewal, D., \& Monroe, K. (1998). Role of prior affect and sensory cues on consumers' affective and cognitive responses and overall perceptions of quality, Journal of Business Research, 42(3), 295-308.

10. Cronin, J.J., Brady, M.K. \& Hult, G.T. (2000). Assessing the effects of quality, value, and customer satisfaction on consumer behavioural intentions in service environments, Journal of Retailing, 76 (3), 193-216.

11. Deloitte (2018). Global Healthcare Outlook, 2018, "The Evolution of Smart Healthcare", https:// www2. deloitte. com/ content/ dam/ Deloitte/ global/ Documents/Life-Sciences- Health-Care/ gx-lshc-hc-outlook-2018.pdf

12. Francis R. (2013). Report of the Mid Staffordshire NHS Foundation Trust Public Inquiry.London:Stationary Office; 2013.

13. Gronroos. C (1984). A service quality model and its marketing implications. European Journal of Marketing 18:36-44

14. Hansemark, O.C.\& Albinson, M., (2004). Customer Satisfaction and Retention: The Experiences of Individual Employees, Managing Service Quality, 14 (1), pp. 40- 57

15. Heskett,J.L., Jones,T.O., Loveman, G.W., Sasser,W.E. \& Schelsinger,L.A. (2011). Putting the service profit chain to work. Harvard Business Review

16. Hoffman, M.L. (1986). Affect, Cognition, and Motivation. In R.M. Sorrentino \& E.T.

17. Hokanson, S.(1995). The Deeper You Analyse, The More You Satisfy Customers, Marketing News, p. 16

18. Hoyer, W. D., \& MacInnis, D. J. (2001). Consumer Behaviour. 2nd ed., Boston: Houghton Mifflin Company

19. International Customer Experience Standard-ICXS 2019:01

20. Jones, T., Sasser, W. and Earl, W. Jr. (1995). Why satisfied customers defect. Harvard Business Review, 73(6), 88-99, Journal of Service Industry Management, 8(2), 148-169.

21. Kantsperger, R., \& Kunz,W. H. (2010). Consumer trust in service companies: a multiple mediating analysis. Managing Service Quality: An International Journal,20(1), 4-25.http://dx.doi.org/10.1108/09604521011011603

22. Kesebir, Pelin and Diener, E.D. (2008). In Pursuit of Happiness Empirical Answers to Philosophical Questions. Perspectives on Psychological Science. Vol3 No 2 ppl17-123.

23. Kesebir, P., \& Diener,E. (2008): In pursuit of happiness: Empirical answers to philosophical questions. Perspectives on Psychological Science , 3, 117-125

24. Laihonen, H., A. Jääskeläinen, and S. Pekkola. (2014). "Measuring Performance of a Service System - From Organizations to CustomerPerceived Performance." Measuring Business Excellence, Vol. 18 No. 3, pp. 73-86. doi:10.1108/MBE-08-2013-0045.

25. Layard, R (2005). Happiness: Lessons from a New Science London: Penguin Press.

26. Liljander, V., \& Strandvik, T. (1997). Emotions in Service Satisfaction, International Journal of Management, Vol.3,pp $92-98$

27. Murphy DJ, Bruce DA, Mercer SW, Eva KW. (2009).The reliability of workplace-based assessment in postgraduate medical education and training: a national evaluation in general practice in the United Kingdom. $A d v$ Health Science Education. 14:219-232. doi: 10.1007/s10459-008-9104-8

28. Oliver, R. (2010). Satisfaction: A behavioural perspective on the consumer. 2nd edition,Wiley Publication.

29. Oliver, R., \& Westbrook, R. (1993). Profiles of consumer emotions and satisfaction in ownership and usage, Journal of Consumer Satisfaction, Dissatisfaction and Complaining Behavior, 6(1), 12-27.

30. Press Ganey (2016). HCAHPS Regulatory Survey. http:// www. pressganey. $\mathrm{com} /$ solutions/ service- a-to-z/hcahps-regulatory-survey Accessed March 20,2016

31. Rust, R. T., \& Zahorik, A.J. (1993). "Customer Satisfaction, Customer Retention and Market Share".Journal of Retailing, 69 (2), 193-215.

32. Ryff, C. D., \& Singer, B. H. (2008): Know thyself and become what you are: A eudaimonic approach to psychological well-being. Journal of Happiness Studies, 9(1), 13-39.

33. Schimmack, U. (2008). The structure of subjective well-being, The science of subjective well-being (pp.97-123). NewYork: Guilford Press.

34. Stenbery, E. (1997). Customer Value Management Concept Creation and Implementation-Case Wartsila Diessel Power Plants. Series

35. Steinman, K.J., Kelleher K., Dembe, A.E., Wickizer, T.M., Hemming, T (2012).The use of a "mystery shopper" methodology to evaluate children's access to psychiatric services.J Behav Health Serv Res. 2012;39:305-13.

36. Watson D, Clark LA, Weber K, Assenheimer JS, Strauss ME, McCormick RA. (1995). Testing a tripartite model: II. Exploring the symptom structure of anxiety and depression in student, adult, and patient samples. Journal of Abnormal Psychology. 104:15-25.

37. White, C. (2010). The impact of motivation on customer satisfaction formation: a self-determination perspective, European Journal of Marketing, Volume $49 /$ Issue $11 / 12$

Web Resource:

1. History of happiness-Aristotle www.pursuit-of-happiness.org

2. Science of happiness www.pursuit-of-happiness.org 